\title{
Sedimentation of Particulate Matter During a Phytoplankton Spring Bloom in Relation to the Hydrographical Regime*
}

\author{
V. Smetacek, K. von Bröckel, B. Zeitzschel and W. Zenk \\ Institut für Meereskunde an der Universität Kiel; Kiel, Germany (FRG)
}

\begin{abstract}
Data presented and discussed here were collected continuously during April/May 1975 in the Bornholm Basin of the Baltic sea. Sedimentation rates of particulate matter were recorded with 5 multisample sediment traps from different depths in the water column at 2 positions $170 \mathrm{~km}$ apart. Current meter data collected during the same period and depths indicated that the positions remained hydrographically distinct during the investigation. Particulate matter from the euphotic zone including diatom cells formed the bulk of the material collected by all traps. This flux of organic particles to the bottom was unimpeded by the strong density stratification present in the water column. The upper traps always collected less material than lower ones. This paradox has been ascribed to diminishing current speeds with depth, concomitant with an increase in sinking rates of phytoplankton and phytodetritus. Both factors influence the sampling efficiency of sediment traps, which are thought to have underestimated actual sedimentation rates here. A time lag of 2 to 3 weeks in bloom development seemed responsible for the characteristic differences between the two positions. The phase of major sedimentation at one position covered about 18 days, and a distinct sequence in the composition of the material collected by the 6 glasses of each trap indicated phases of a progressively deteriorating phytoplankton population in the water column contributing the particulate material. A total of $6.2 \mathrm{~g} \mathrm{C} \mathrm{m}^{-2}$ in 34 days was recorded at this station. Apart from a trap situated in an oxygen deficient layer which collected $0.44 \mathrm{~g} \mathrm{c} \mathrm{m}^{-2}$ of zooplankton corpses, zooplankton mortality was overestimated by the traps. Large-scale sedimentation of "fresh" organic matter produced by the spring bloom is probably a regular feature in areas with low over-wintering zooplankton populations and, as such, possibly has a direct stimulatory effect on growth and reproduction of the benthos.
\end{abstract}

\section{Introduction}

The quality and quantity of organic matter settling out of surface layers is of vital importance to all heterotrophic life below the euphotic zone. The processes by which particulate organic matter reaches the sea bed, a fundamental aspect of sediment/water column interaction, has received comparatively little attention in the literature. This is due largely to the methodological difficulties involved in measuring rates and mechanisms of this vertical transport.

sediment traps have been used to directly measure the flux of particulate matter to the sediments, although in ma-

*Contribution No. 185 of the Joint Research Programme 95, Kiel University. rine environments their use has generally been restricted to shallower inshore areas (Parsons et al., 1977). In this paper, data on short-term dynamics of sedimentation of particulate matter in the Bornholm Basin (Southwest Baltic Sea), derived from sediment traps, are discussed in conjunction with detailed hydrographical measurements for the same period and area.

Data were collected during the joint physical/chemical/biological experiment "Baltic 75" conducted during April/May 1975 in the Bornholm Basin. Physical parameters and data on sedimentation were recorded continuously by moored instruments, and profiles of various parameters were taken from anchored ships. Cruise reports and data have been published by Keunecke et al. (1975) and Kielmann et al. (1976). 
Bottom topography of the area and the position of the moorings are given in Fig. 1. The Bornholm Basin represents one of a series of basins and sills on a longitudinal section through the Baltic sea. Its deepest inlet from the west is formed by the Bornholm Gat $(45 \mathrm{~m})$, divided into 2 channels between the island of Bornholm and the Swedish coast (Kögler and Larsen, in press). The Stolpe Ridge $(60 \mathrm{~m})$ represents the outlet towards the Gotland Sea. The Bornholm Basin measures $105 \mathrm{~m}$ at its deepest part.

The two recovered moorings carrying sediment traps were installed in topographically different locations. "Max" ("Baltic 75" Station 4) was situated $\mathrm{NE}$ of the island of Bornholm in $64 \mathrm{~m}$ depth. The site is best described as a plateau on the wall of a $75 \mathrm{~m}$ deep channel dividing the island and the $10 \mathrm{~km}$ distant Christiansö-Bank. An interaction between bottom topography and current systems can be expected at this location. In contrast, "Moritz" ("Baltic 75" Station 9)

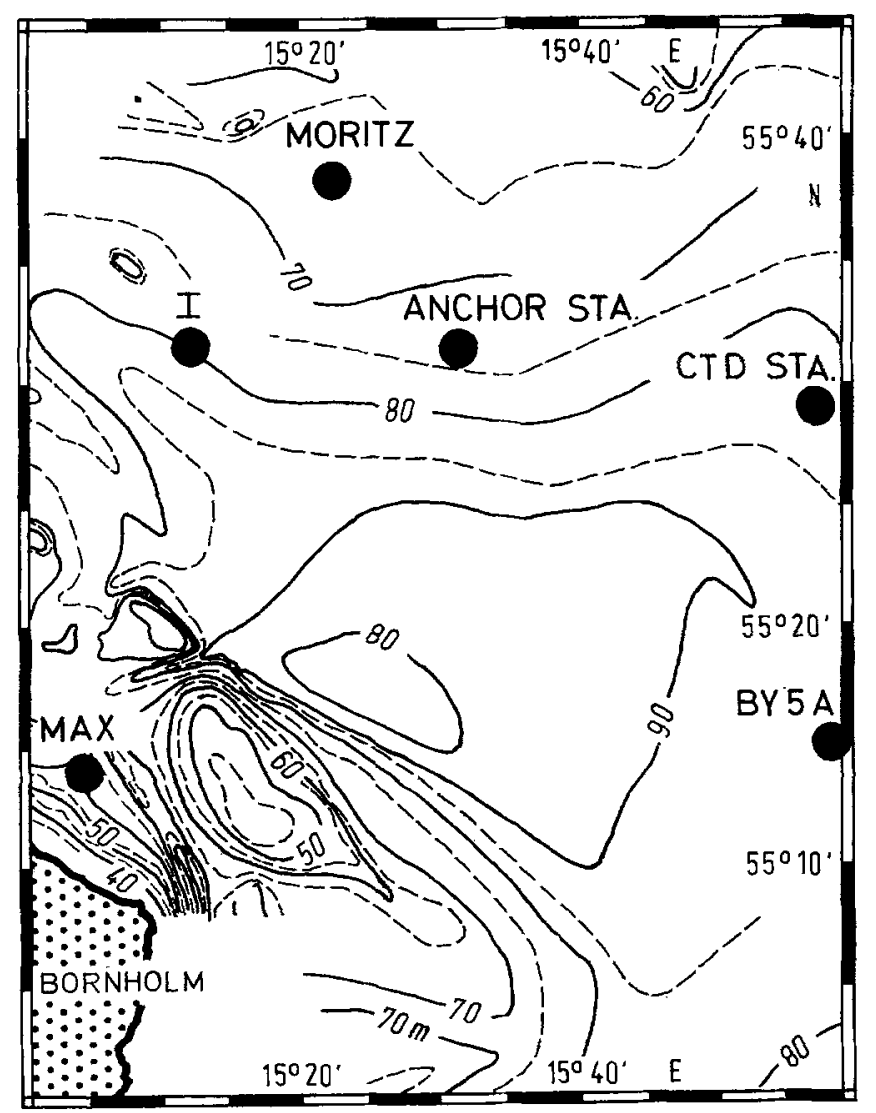

Eig. 1. Bathymetric chart of sw part of Bornholm Basin (after Kögler and Larsen, in press). Moorings at "Max" and "Moritz" carried sediment traps and various current/temperature/conductivity (CTD) recorders. Also included are Location I of the moored wind recorder, Station "CTD", and the anchor station. Station BY5A was occupied by Matthäus et al. (1976) was chosen in an open area of the Bornholm Basin. This site showed a rather smooth bottom relief at a depth of $70 \mathrm{~m}$. An anchor station was occupied by R.V. "Meteor" from 17 to 26 April in the vicinity of "Moritz". All positions were situated below the $60 \mathrm{~m}$-isobath. This depth contour is the shallowest isobath that forms a closed curve around the Bornholm Basin (Simons, 1976), and is identical with the eastern sill depth (Stolpe Ridge).

Characteristic for the hydrography of the Baltic, an inland sea in a humid area, is the excess of low-salinity surface water flowing into the North Sea. The volume of this outflow is of the same order of magnitude as the river discharge into the Baltic, as precipitation and evaporation cancel each other on the average (Dietrich and Schott, 1974).

Due to the difference in densities between North Sea and Baltic Sea water, an inflow of the former, controlled by meteorological forcing and by bottom topography, occasionally takes place (Siedler and Hatje, 1974). This leads to the characteristic halocline in the Baltic sea, which increases in depth from the inlet (Kategatt) towards the central Baltic. The higher salinity bottom waters in the deeper basins, including the Bornholm Basin, have residence times from months to years and are generally deficient in oxygen. Local overturning under extreme meteorological conditions in winter can occur sporadically and renew the stagnating water in the deeper basins (Krause, 1969).

\section{Materials and Methods}

\section{Field Set-up}

Hydrographical profiles were obtained using a CTD-system (conductivity, temperature, depth) by Howaldt (Bathysonde). Data processing and instrument characteristics agreed with Peters' (1976) report on calibration and editing of CTD data.

current meters and sediment traps were placed in separate legs of twolegged mooring arrays $110 \mathrm{~m}$ apart, as described by Keunecke et al. (1975) and zeitzschel et al. (1978). Self-recording Aanderaa current meters equipped with temperature sensors were placed at 15, $25,35,55$ and $61 \mathrm{~m}$ levels at "Max" and at $15,35,55$ and $67 \mathrm{~m}$ depths at "Moritz". The bottommost unit recorded conductivity as well. The multisample sediment traps employed in this investigation have been described by Zeitzschel et al. (1978). With this type of sediment trap it is possible to obtain 8 successive samples for predetermined time intervals. 
Details of the sampling procedure are given in Table $1.0 .5 \mathrm{~cm}^{3}$ of chloroform was added beforehand to each glass as a preservative. Hendrikson (1975) found that chloroform, while otherwise well suited for this purpose, tends to convert chlorophyli to pheopigments but prevents further breakdown that inevitably takes place if no preservative is used.

\section{Anchor Station}

Discrete samples were collected from 12 depths in the water column at $8 \mathrm{~h}$ intervals and analysed in the same manner as the sediment trap samples. Zooplankton was sampled by vertical net hauls. This station was occupied from 17 to 26 April, 1975 .

\section{Analysis of Collected Material}

The material collected in each glass was strained through $300 \mu \mathrm{m}$ gauze to remove larger zooplankton and then suspended in a known volume of filtered sea water. Subsamples for the analyses described below were pipetted from this suspension, kept homogeneous by agitation.

The zooplankton was counted under a stereo-microscope, and counts were converted to biomass using factors derived from direct measurements of a number of individuals.

Dry weight (DW) of particles $<300 \mu \mathrm{m}$ was determined on membrane filters with a pore size of $0.8 \mathrm{um}$, according to the method of Lenz (1971).

Particulate organic nitrogen (PON) and carbon (POC) were measured with a $\mathrm{CHN}$ analyzer (Hewlett-Packard, 185 B) on precombusted whatman GF/C filters which were treated with dilute HCl before measurement. Chlorophyll a and pheopigment analyses were carried out as recommended by UNESCO (1966), using a cell-mill for homogenizing samples (Derenbach, 1969). Spectrophotometric equations given by Lorenzen (1967) were used for calculating chlorophyll and pheopigments. Both values were added together and are referred to as chlorophyll a equivalents (chl. a equiv.) below.

Phytoplankton carbon (PPC) was calculated from cell counts, obtained by inverted microscopy, using conversion factors for species and size groups given by Smetacek (1975).

\section{Results}

\section{Physical Parameters}

Selected temperature, salinity and density profiles obtained from station CTD (see Fig. 1), covering the period 19 April to 25 May, are given in Fig. 2. The water column down to a depth of about $50 \mathrm{~m}$ was homogeneous on 19 April; its abnormally high temperature $(4 \circ \mathrm{C})$, compared to the long-term mean (dashed line in Fig. 2), was due to the mild winter of 1974/1975 (Matthäus et al., 1976). Temperature time series from the moored instruments (Fig. 3) show that the buildup of thermal stratification started on 21 April at both stations. The characteristic development of the seasonal thermocline with downward migrating layers to a depth of about $35 \mathrm{~m}$ is shown by the profiles after 19 April. The density profiles reflect mainly the saline structure, and clearly show the stable halocline at $55 \mathrm{~m}$ depth present throughout the experiment. The water mass below this transition layer was characterised by higher temperature and lower oxygen levels (Grasshoff, personal communication) than the upper layer. Because of

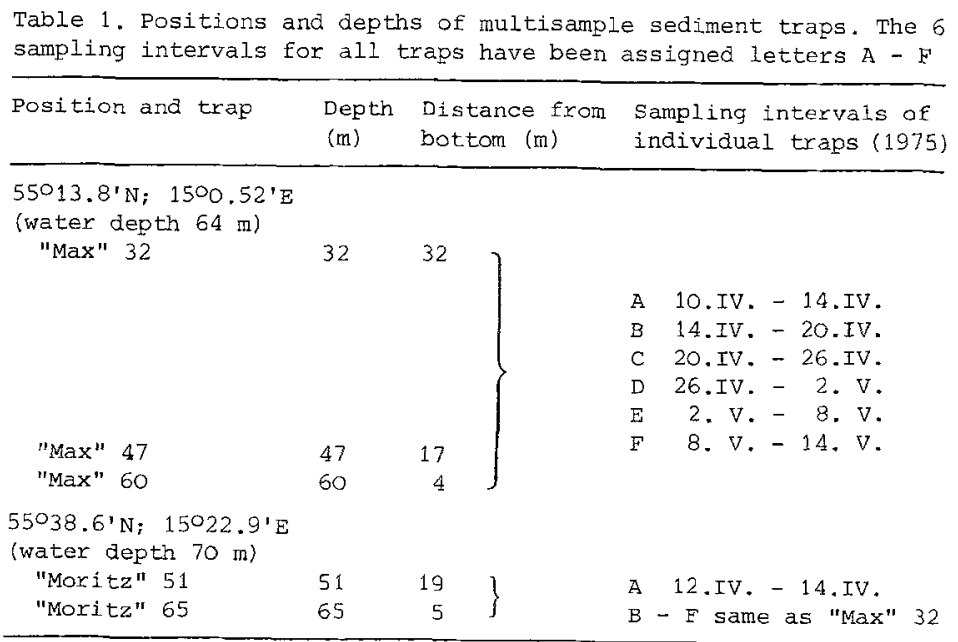



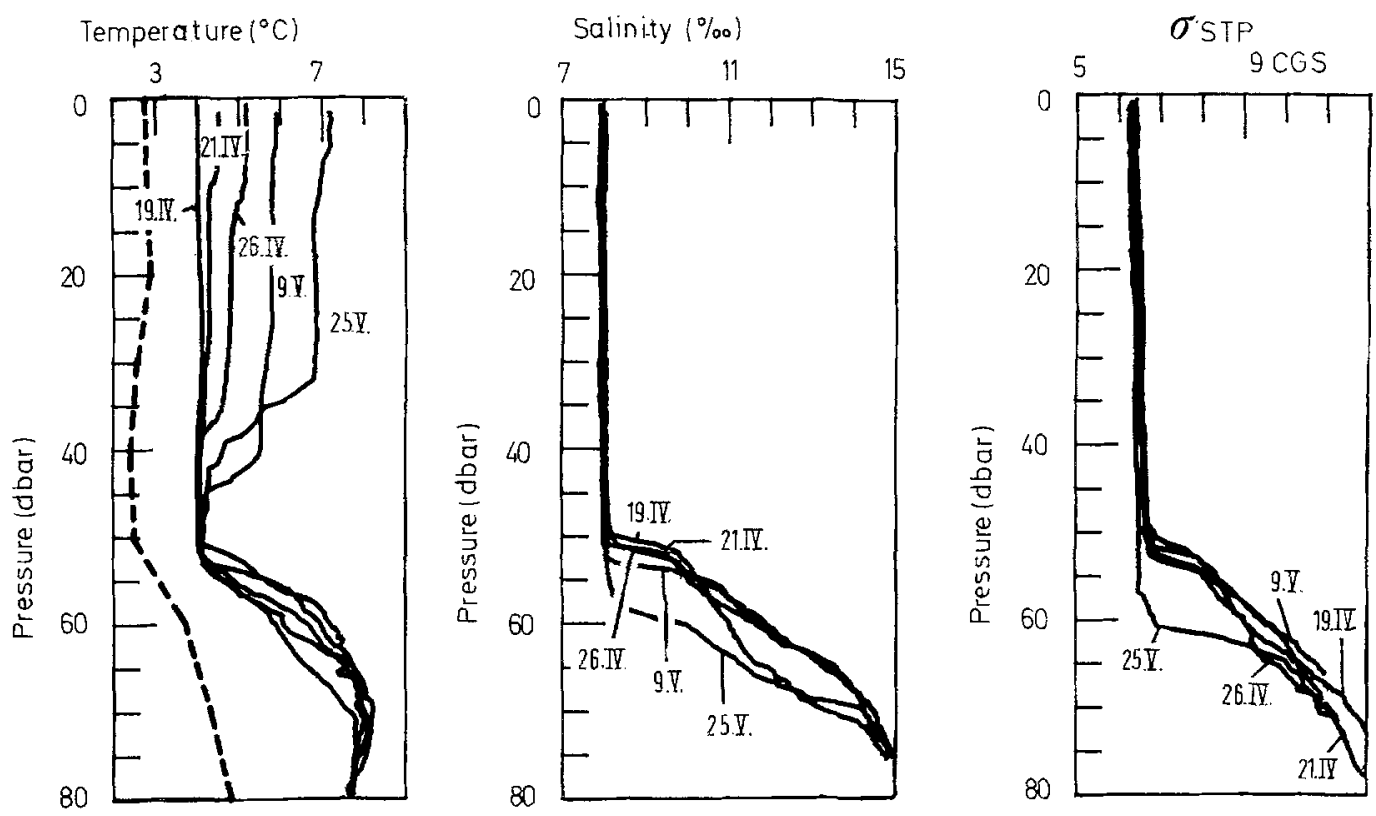

Fig. 2. Development of seasonal thermocline at Station "CTD". In spring 1975, temperature of total water column showed a positive anomaly of $2{ }^{\circ} \mathrm{C}$ (according to Matthäus et al., 1976). Long-term mean profile is depicted by dashed line ( $\delta \mathrm{STP}=$ in situ density parameter in CGS units: conductivity, temperature, depth)

its higher temperature, this water could only have entered the Bornholm Basin before the previous winter, indicating a residence time here of at least 6 months. As temperature and salinity were always positively correlated, it can be presumed that little if any renewal of higher salinity subhalocline water through the $45 \mathrm{~m}$ Bornholm Gat took place during the experiment.

Time series of wind and current speed as well as direction are depicted in Figs. 4 and 5. A positive correlation between wind speed and currents existed in the upper layer, i.e., the surface current system was predominantly winddriven. Current direction at "Max" and "Moritz", however, differed somewhat. This is best seen from the progressive vector diagrammes in Fig. 6. These diagrammes trace the theoretical path of a water particle in time, and should not be regarded as a measure of large-scale or long-term water transport, as the underlying assumption of a homogeneous current field is at best highly restricted in time and space. At "Max", currents were generally paraliel to the coast, with net surface transport to the NW interrupted by intermittent reversals in flow direction. At "Moritz", currents were predominantly westerly, indicating net surface transport of water past "Moritz" from NE to SW. However, simultaneous data from other current meters in the Bornholm sea frequently showed reverse directions. "Moritz" was situated fairly in the centre of a region of eddy formation, generated by the interaction of wind stress and bottom topography. The predictions from a numerical model computed for the southwest Baltic further confirms this circulation pattern (Simons, 1976).

Because of this large-scale vorticity, the residence time of surface water in the Bornholm sea is probably longer than indicated by data from the current meters moored at "Moritz". However, a more or less steady admixture of open Baltic sea water from the North and East to the circulating water of the Bornholm sea must have occurred during the experiment. The level of the halocline differed by several meters at the two stations, although its level rose and fell intermittently during the experiment as shown by the temperature time series from the $62 \mathrm{~m}$ and the $55 \mathrm{~m}$ depths at "Max" and "Moritz" respectively (Fig. 3). The abrupt peaks and troughs in the curves for these depths demonstrate changes in the halocline level. The temperature record from $67 \mathrm{~m}$ at "Moritz" showed that the halocline was constantly above this level except for a 5-day period from 3 to 8 May. Thus, the traps "Max" 32 and "Max" 47 were situated throughout in the intermediate layer between euphotic zone $(25$ to $30 \mathrm{~m}$ ) and halocline and "Moritz" 65 

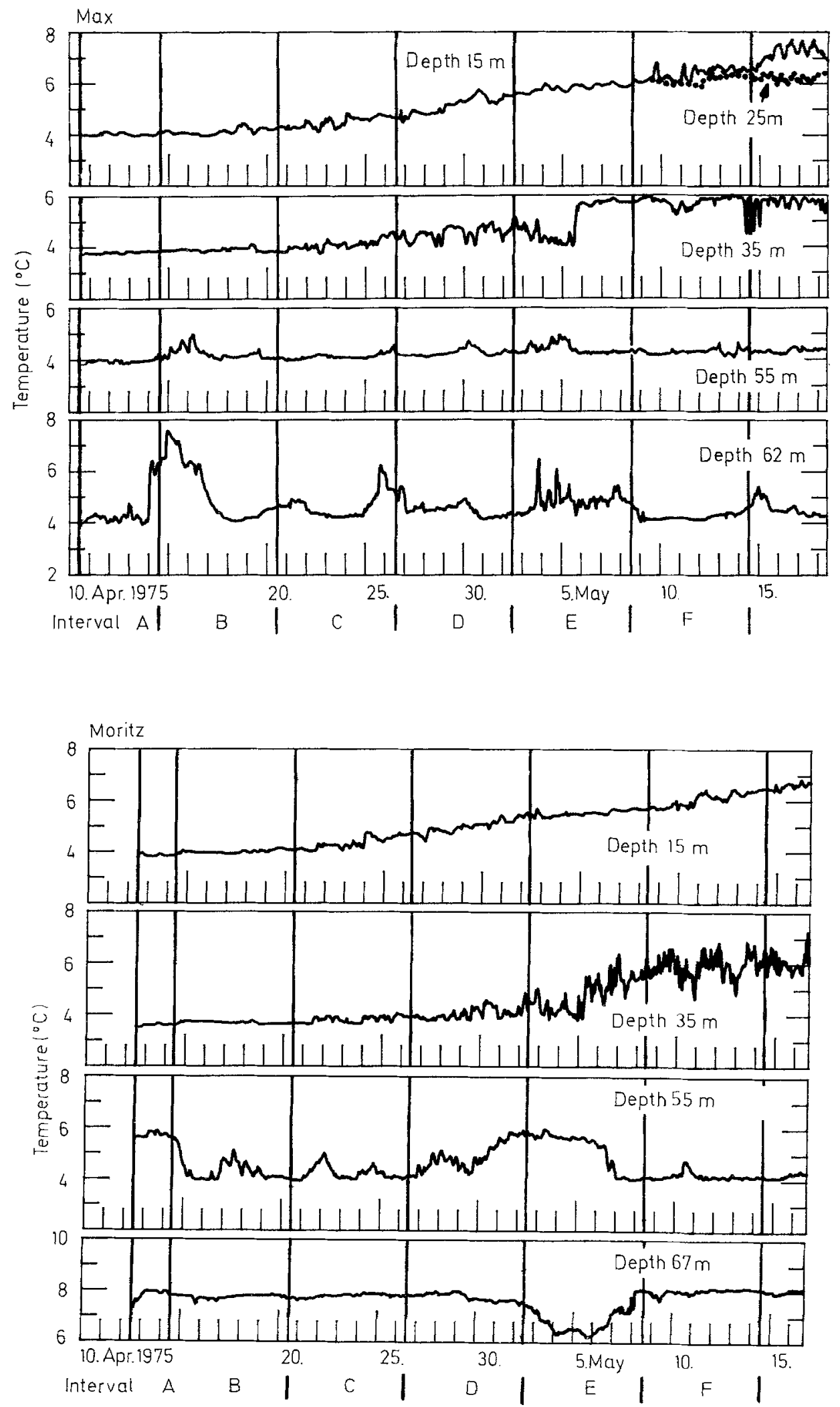

Fig. 3. One-hour-averaged temperature time series from different depths recorded at "Max" and "Moritz" from 10 April to 16 May. Vertical lines denote sampling intervals (A - F) of individual glasses of sediment traps. Until 10 May at "Max", temperature gradient between 15 and $25 \mathrm{~m}$ levels was negligible, therefore, the temperature series from $25 \mathrm{~m}$ depth is depicted only for the last period $F$ ( 8 to 14 May). Note shifted scale on ordinate from "Moritz" $67 \mathrm{~m}$ 

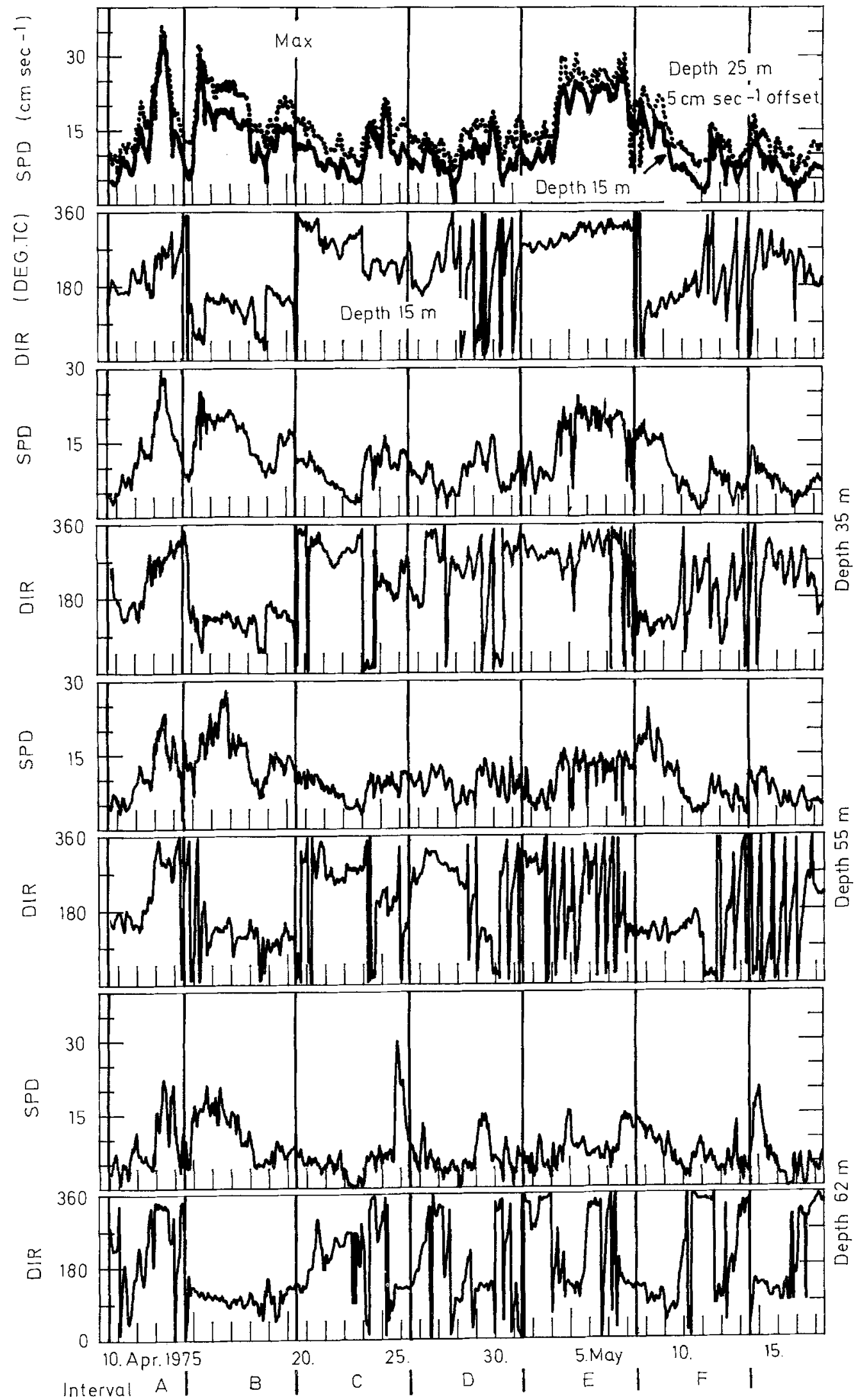

Fig. 4. One-hour-averaged time series of current speed (SPD) in $\mathrm{cm} \mathrm{sec}^{-1}$ and direction (DIR) in degree true current recorded at "Max" from 10 April to 17 May. To demonstrate the great similarity in current speeds between 15 and $25 \mathrm{~m}$ depths, indicative of low shear in the top layer, the series from these depths are combined in uppermost diagramme. The ordinate for $25 \mathrm{~m}$ depth curve is shifted $5 \mathrm{~cm}$ $\mathrm{sec}^{-1}$ higher than for curve from $15 \mathrm{~m}$ depth to avoid overlapping. Decreasing current speed and increasing influence of topography with depth is reflected in diagrammes from $62 \mathrm{~m}$ depth. Vertical lines denote sampling intervals $(A-F)$ of individual glasses of sediment traps. DEG TC $=$ degree true current 


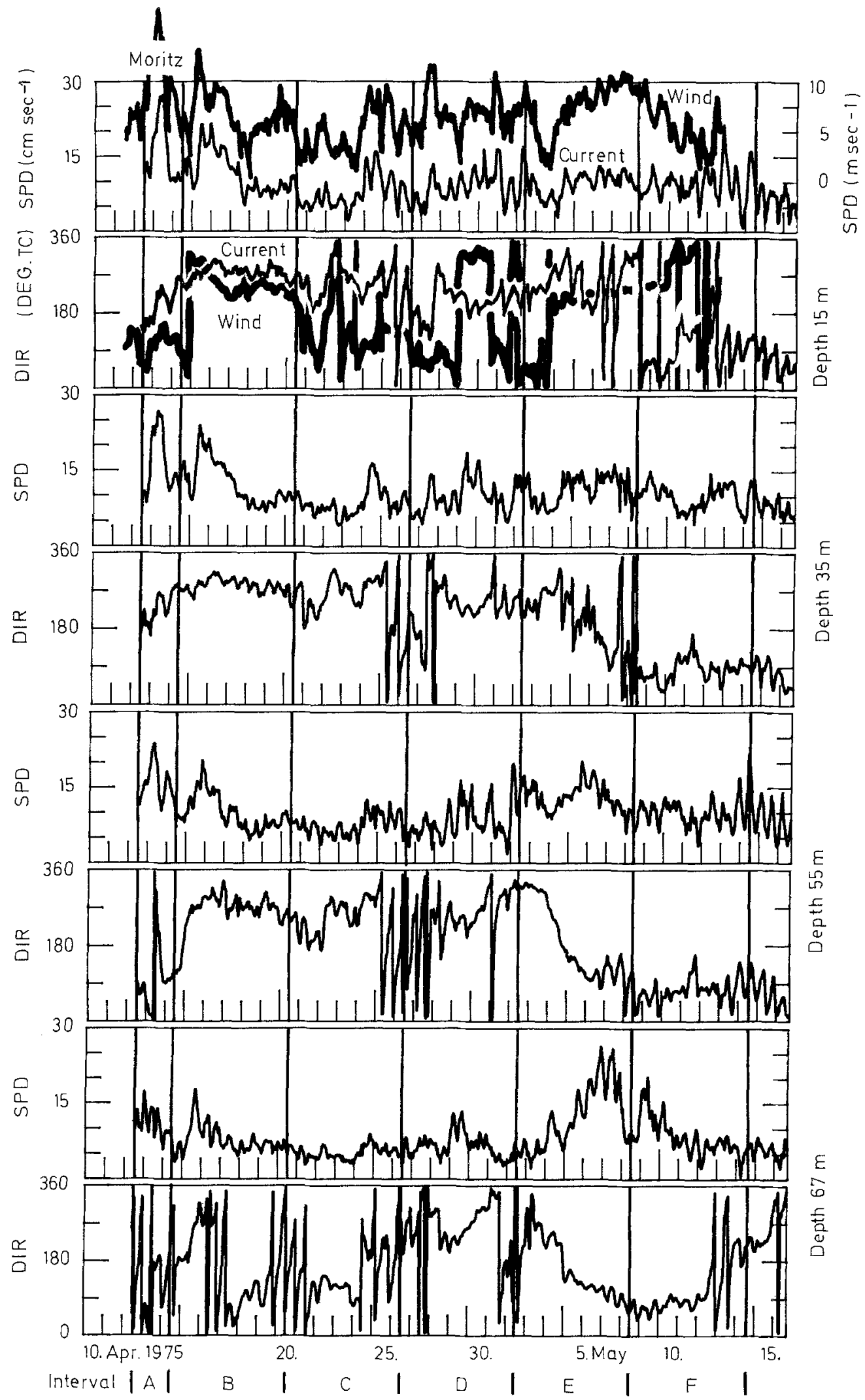

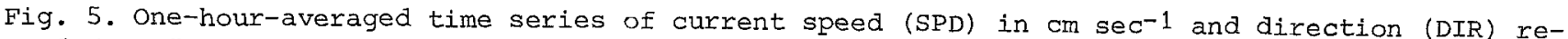
corded at "Moritz" from 10 April to 16 May together with wind data (speed in $\mathrm{m}$ sec-1) recorded at Location $I$. Wind and current directions are given uniformly according to oceanographic usage (oo = towards N) 


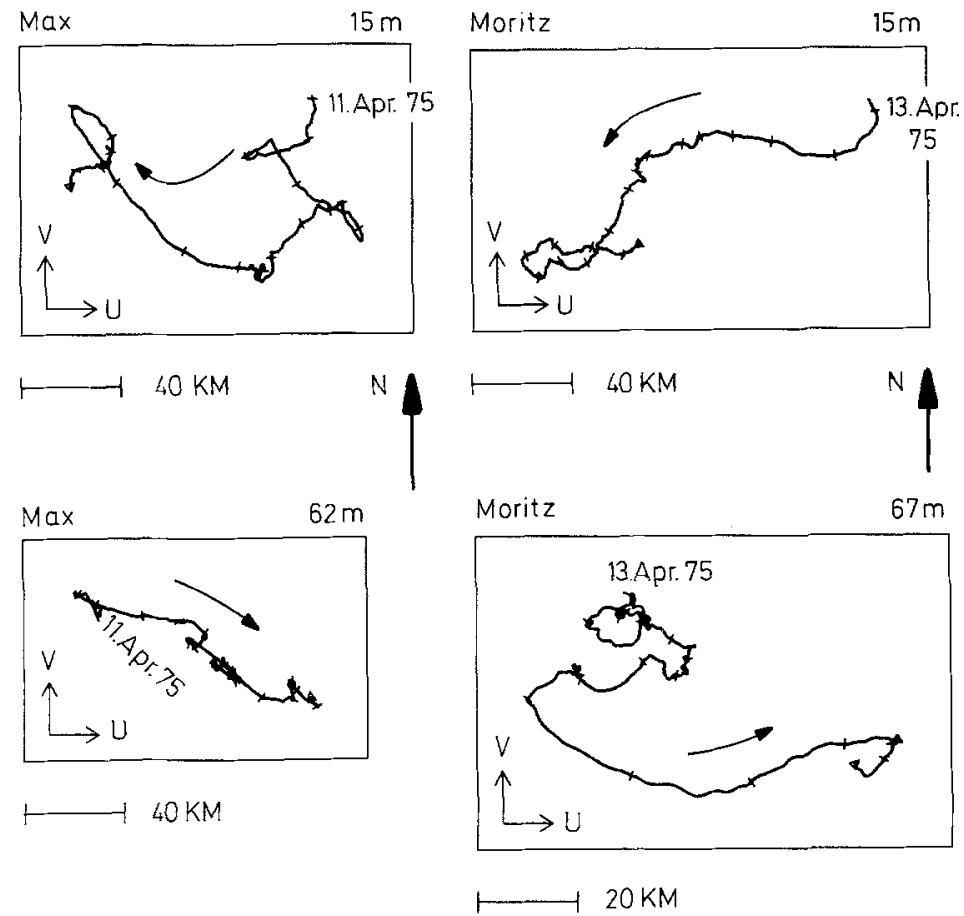

Fig. 6. Progressive vector diagrammes from $15 \mathrm{~m}$ levels and bottomost current meters at "Max" and "Moritz". Data were averaged hourly before plotting. Dashes indicate 2-day intervals from $11 / 12$ April to 14 May 1975. Note different scale for "Moritz" $67 \mathrm{~m}$. ( $\mathrm{U}$ and $\mathrm{V}=$ East and North components of velocity, respectively) was located, with the one exception, con-
stantly below it. Current speeds generally decreased with depth, although considerable speeds were sometimes recorded at the halocline level. At both stations, currents below the halocline were much slower and generally in an opposite direction to those in the surface layers (Fig. 6).

\section{Anchor Station}

The euphotic zone extended to about 25 to $30 \mathrm{~m}$ and, before 19 April, was not Iinked to any measurable density stratification above the halocline. A large phytoplankton population $\left(3 \mathrm{~g} \mathrm{C} \mathrm{m}^{-2}\right.$ and $110 \mathrm{mg}$ chlorophyll a $\mathrm{m}^{-2}$ ) was fairly evenly distributed in the upper $30 \mathrm{~m}$ at the start of sampling at the anchor station. Phytoplankton concentrations were much lower in the intermediate layer between the euphotic zone and the halocline, and below the latter hardly any cells were present except for one brief occasion.

Total net primary production measured during the 10 days was $12.6 \mathrm{~g} \mathrm{C}^{-2}$, and highest production values were recorded on the 21 April $\left(2.4 \mathrm{~g} \mathrm{C} \mathrm{m}^{-2}\right)$, concomitant with an increase in irradiation and a decrease in wind speed. The low zooplankton biomass, which ranged between 0.40 and $0.45 \mathrm{~g} \mathrm{C} \mathrm{m}^{-2}$, was equivalent to roughly $4 \%$ of $\mathrm{POC}$ in the water column.

\section{Sediment-Trap Material}

Dry weight of the settled material and its organic carbon, phytoplankton carbon and chlorophyll a equivalent content collected by the different traps during the 6 periods are depicted in Figs. 7 and 8 . All values are in $\mathrm{mg} \mathrm{m}^{-2} \mathrm{day}^{-1}$.

Several striking features regarding quantity and qualitative composition of the material collected are apparent from Figs. 7 and 8 .

Distinct time sequences in the amount collected by the traps at the two stations are evident. At "Max", low sedimentation rates from 10 to 20 April preceded a 2- to 3-fold increase from 20 April to 8 May, followed by a decline after $8 \mathrm{May}$. At "Moritz", on the other hand, both traps show a steady increase in sedimentation rate from 20 April onwards, with exceptionally high values from 8 to 14 May. The low values recorded by "Moritz" 65 from 2 to 8 May are an exception to this trend. 
The lowest traps at both stations collected considerably more material than the upper traps. This appears more clearly in Table 2, where total quantities of different parameters for the entire period from the different traps are given.

At "Moritz", a consistent difference in the quality of the material collected by the two traps is evident (Fig. 9). The particulate material settling into the lowest trap ("Moritz" 65) appeared to be "fresher" than that collected by the upper trap. This is indicated by lower POC:PON and POC:chl. a equiv. ratios and a higher percentage contribution of PPC to POC. The lower POC percentage of dry weight is probably due to the relatively larger number of diatom cells and their remains which contributed inorganic matter in the form of silica frustules.

Correlations between dry weight (DW) of the particulate matter and its organic carbon (POC), phytoplankton carbon

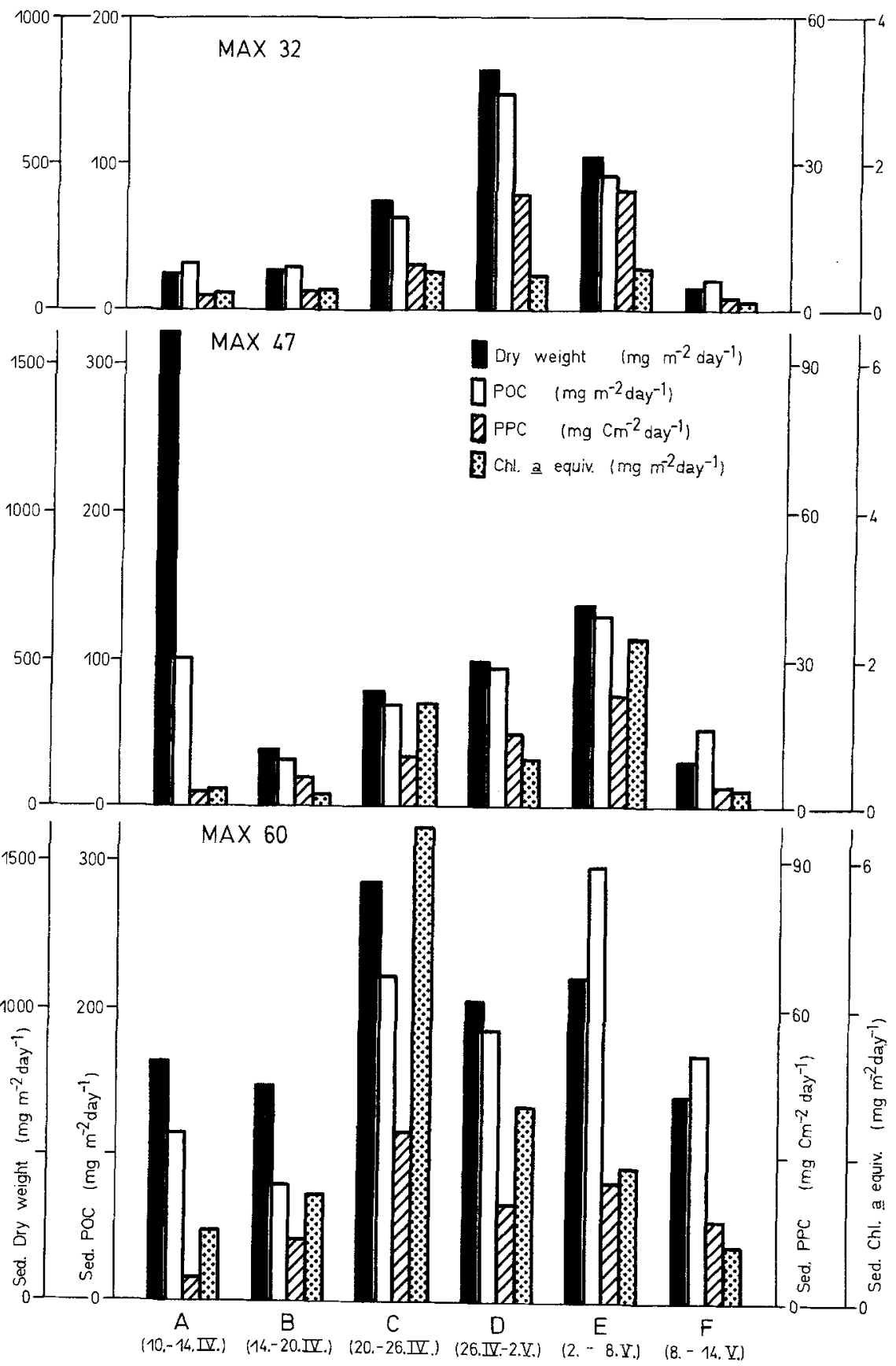

Fig. 7. Dry weight, particulate organic (POC) and phytoplankton (PPC) carbon and chlorophyll a equivalent of sedimented material collected by traps "Max" 32, "Max" 47 and "Max" 60 during 6 sampling intervals A - F. Water depth was $64 \mathrm{~m}$ 


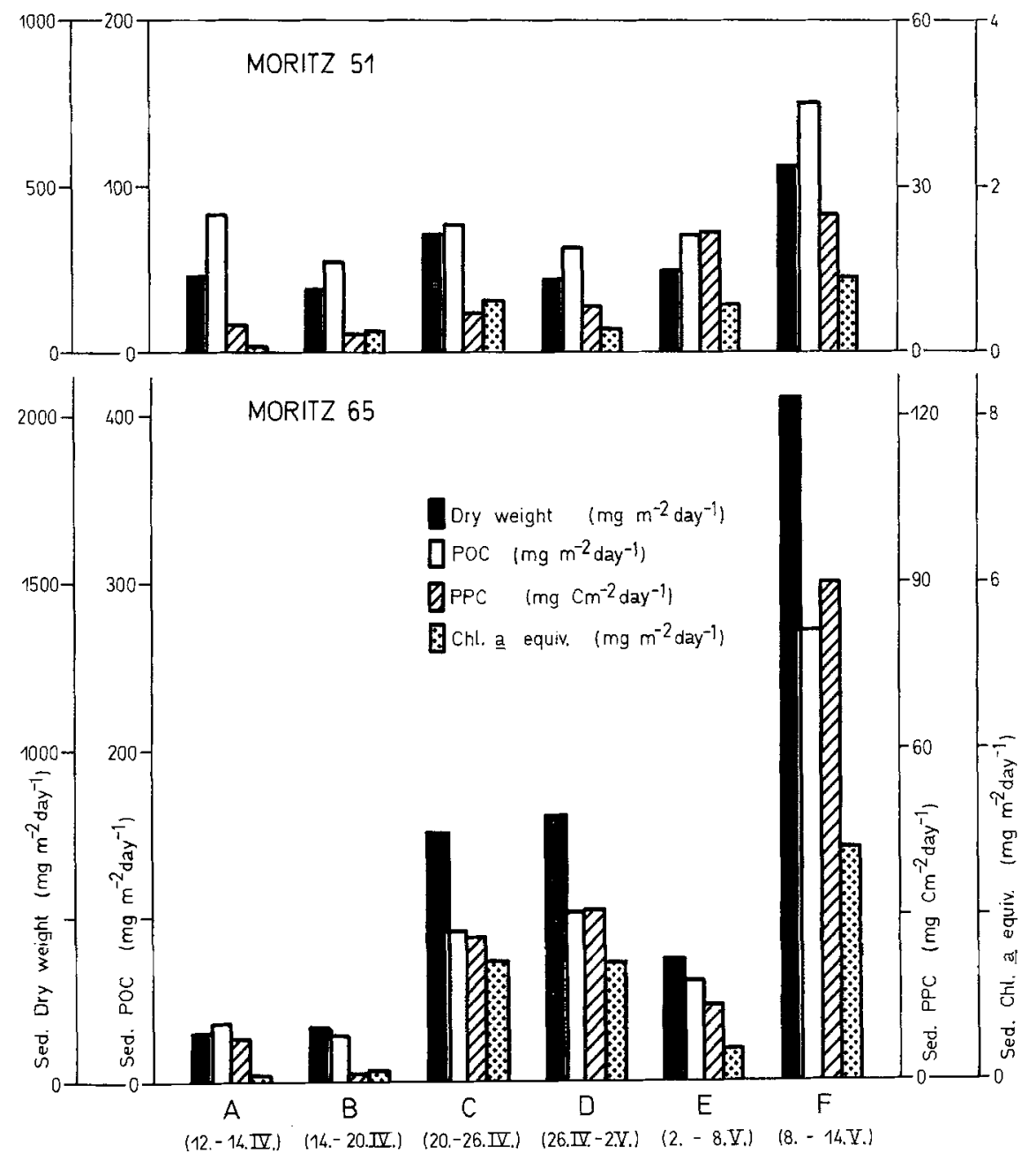

Fig. 8. Dry weight, particulate organic (POC) and phytoplankton (PPC) carbon and chlorophyll a equivalent of sedimented material collected by traps "Moritz" 51 and "Moritz" 65 during sampling intervals $A-F$. Water depth was $70 \mathrm{~m}$

Table 2. Total quantities of sedimented material collected in traps for time period 10 April to 14 May, 1975. DW: Dry weight; Zoopl.: zooplankton; POC, PON: particulate organic carbon and nitrogen, respectively; PPC: phytoplankton carbon; chl. a equiv.: chlorophyll a equivalents

\begin{tabular}{|c|c|c|c|c|c|c|}
\hline $\begin{array}{l}\text { Trap no. and } \\
\text { distance from } \\
\text { botton }\end{array}$ & $\begin{array}{l}D W<300 \mu m \\
\left(g m^{-2}\right)\end{array}$ & $\begin{array}{l}200 p 1 .>300 \mu \mathrm{m} \\
\left(\mathrm{g} \mathrm{C} \mathrm{m}^{-2}\right)\end{array}$ & 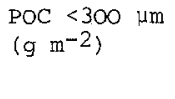 & $\begin{array}{l}\text { PON <300 } \mu \mathrm{m} \\
\left(9 \mathrm{~m}^{-2}\right)\end{array}$ & $\begin{array}{l}\mathrm{PPC} \\
\left(\mathrm{g} \mathrm{m}^{-2}\right)\end{array}$ & $\begin{array}{l}\text { chl. a equiv. } \\
\text { (g m-2) }\end{array}$ \\
\hline $\operatorname{Max} 32(32 \mathrm{~m})$ & 11.30 & 0.58 & 2.274 & 0.301 & 0.392 & 0.013 \\
\hline $\operatorname{Max} 47(17 \mathrm{~m}\}$ & $11.48^{\mathrm{a}}$ & 1.38 & 2.697 & 0.317 & 0.357 & 0.030 \\
\hline $\operatorname{Max} 60(4 \mathrm{~m})$ & 32.97 & 2.84 & 6.220 & 0.625 & 0.677 & 0.083 \\
\hline Moritz $51(19 \mathrm{~m})$ & 9.86 & 1.67 & 2.671 & 0.289 & 0.369 & 0.015 \\
\hline Moritz $65(5 \mathrm{~m})$ & 25.04 & 0.44 & 3.403 & 0.410 & 0.984 & 0.037 \\
\hline
\end{tabular}

"Sanple "Max" 47 A not included. 


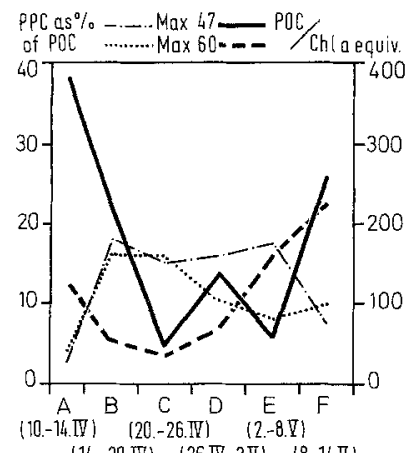

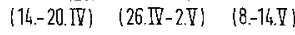

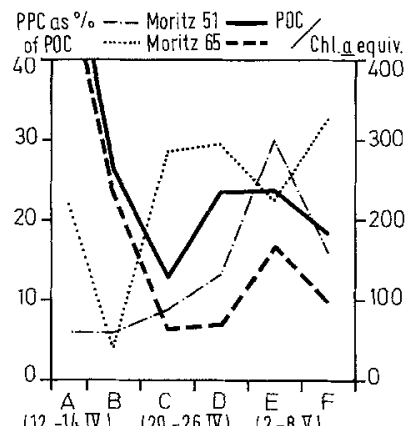

(12. $-34 . \pi) \quad.(20 .-26 . \bar{T}) \quad(2-8.7)$

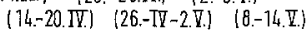

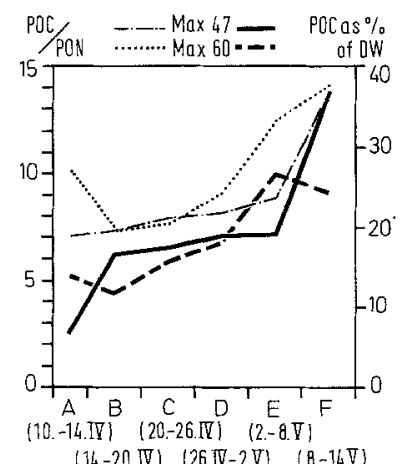

$(14 .-20.17) \quad(26.17-2.7) \quad(8 .-14.7)$

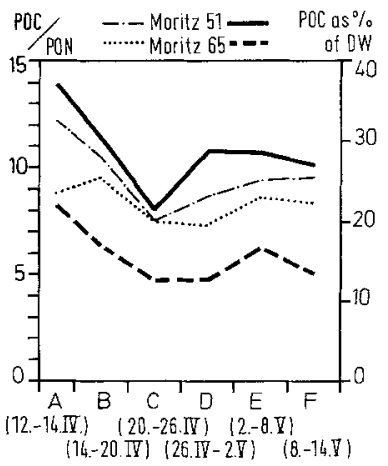

$(14 .-20 . T) \quad(26.77-2.7) \quad(8 .-14.7)$

Fig. 9. Ratios of some properties of seaimented matter from "Max" 47 and "Max" 60, "Moritz" 51 and "Moritz" 65. Phytoplankton carbon (PPC) as percentage of particulate organic carbon (POC), ratio of particulate organic carbon (POC) to chlorophyll a equivalent (chl. a equiv.), particulate organic carbon to nitrogen ratio (POC/ PON), and particulate organic carbon (POC) as percentage of particulate dry weight (DW)

(PPC) and chlorophyll a equivalent (chl. a equiv.) proved to be highly significant when the contents of all the glasses $(n=29)$ were compared (Table 3). "Max" 47 , 10 to 14 April, was not included because its unusually high dry weight was caused by impurities. This relative homogeneity of the material collected by the different glasses at different depths indicates a common origin. Plankton and detritus sedimenting out of the water column as well as particulate matter resuspended from the sediment surface are the only two potential sources if terrestrial input is negligible, which appeared to be the case here.

Surface sediment from the Bornholm Basin has an organic carbon and chl. a equiv. percentage of DW of $3 \%$ and $0.01 \%$, respectively (Plankton Group SFB 95, unpublished data). The corresponding values from sediment trap material were much higher, and ranged between 14-27\% and $0.12-0.26 \%$ respectively. From these values, and from the comparison between

Table 3. Linear regression between dry weight (DW) and organic carbon (POC), phytoplankton carbon (PPC) and chlorophyll a equivalent (chl. a equiv.) of material from the traps and from water column (seston) in same units, where $r=r e-$ gression coefficient, $a=$ intercept, $b=$ slope according to $Y=a+b X$

\begin{tabular}{ccccc}
\hline$X \quad Y$ & $r$ & $a$ & $b$ & $n$ \\
\hline Trap material & & & & \\
DW:POC & $0.90^{* * *}$ & 22.7 & 0.144 & 29 \\
DW:PPC & $0.88^{* * *}$ & -1.8 & 0.033 & 29 \\
DW: chl. a equiv. & $0.77^{* * *}$ & -0.15 & 0.002 & 29 \\
Seston & & & & \\
DW:POC & $0.76^{* * *}$ & 22.3 & 0.199 & 111 \\
DW:PPC & $0.77^{* * *}$ & -24.9 & 0.130 & 106 \\
DW: chl. a & $0.61 * * *$ & 0.49 & 0.002 & 119 \\
\hline
\end{tabular}

***Correlations significant at $0.1 \%$ level.

sediment trap material and seston from the entire water column in Table 3 , it is obvious that particulate matter collected by the traps was indeed seston from the water column, since even a minor addition of resuspended matter would have significantly altered the composition of the material in the traps. Besides, the upper traps were out of reach of resuspended material because of the pycnocline, but they nevertheless collected essentially the same material as the lower traps, situated only $5 \mathrm{~m}$ above the bottom.

It can be seen from Table 3 that the slopes of the regression lines for DW: chl. a from seston and trap material are very similar, although much more chl. a equiv. was present in the glasses than could be accounted for by cell counts, indicating a higher percentage of phytodetritus to total $D W$ in the glasses compared to seston in the water column. Similarly, the lower POC content of DW in the traps compared to the value from the water column is most probably due to the fairly large quantities of empty diatom frustules collected by the traps.

The species composition of phytoplankton collected in the traps remained fairly constant throughout the 5 weeks, and was much the same as that recorded in the water column. The diatom skeletonema costatum, with chains containing up to 8 cells, was by far the major contributor to the biomass, although larger centric diatoms were also of importance.

Although the material collected by the traps was relatively homogeneous, the temporal variations in the ratios for POC:PON, PPC:POC, POC:chl. a equiv. and $D W: P O C$ follow distinct trends, as shown by individual glasses of the dif- 
ferent traps, indicating steady changes in the composition of the material collected by the traps during the investigation period. From Fig. 9 it can be seen that the ratios for POC:PON, POC: chl. a equiv., and for POC as percentage of DW show the same trends and are inversely related to PPC percentage of POC. This relationship and the consistency of the trends at the different positions is most clearly seen in the curves representing the lowest traps.

At "Max", Iow POC:PON ratios from 14 to 26 April coincide with the onset of increased sedimentation, whereas the very high ratios from 2 to 14 May are related to a stabilization and decline in sedimentation. Presumably, major sedimentation of particulate matter produced during the spring bloom started during the period 14 to 20 April, with POC:PON and POC:chl. a equiv, ratios similar to those recorded from the water column. Thereafter, with the decline of the spring bloom, the characteristic symptoms of a progressively deteriorating phytoplankton population were observed in the material collected by subsequent glasses. The decrease in phytoplankton percentage of POC was accompanied by inCreasing POC:PON, POC: ch1. a equiv. and DW:POC ratios, the latter being presumably due to the corresponding decline in diatom frustules.

At "Moritz", moderate sedimentation of particulate matter from the spring bloom started from 14 April onwards, with major sedimentation taking place during the last period (8 to 14 May). A decline phase, similar to that recorded at "Max" was not observed here, presumably because major sedimentation continued after 14 May.

The material collected at "Moritz" 65 from 2 to 8 May deviated both qualitatively and quantitatively from the trend typical for this trap. The deepening of the halocline was recorded during this period, and was accompanied by a substantial increase in the current speeds typical for this depth. The environment around "Moritz" 65 was similar to that around "Moritz" 51 during 5 days of this 6-day period and the material collected by both traps was similar in both quantity and composition (Figs. 8 and 9).

The large numbers of zooplankters collected by the traps were generally in good condition. They seemed to have actively entered the traps and then been killed and preserved by the chloroform in the glasses. At "Max", their numbers also increased with depth, a phenomenon most probably related to their normal vertical distribution above the halocline. However, as "Moritz" 65 was lo- cated almost continuously in the oxygendeficient layer below the halocline, zooplankton collected here was probably the result of natural mortality. The mangled and partly decomposed condition of the corpses compared to those from other traps supported this supposition. The sample collected from 2 to 8 May also proved exceptional with regard to zooplankton, displaying a value higher than in other samples. In all, a total of $0.44 \mathrm{~g} \mathrm{C} \mathrm{m}^{-2}$, equivalent to $10 \%$ of sedimented POC, was collected in the form of zooplankton corpses ( 95\% Pseudocalanus elongatus) by "Moritz" 65 during the entire period. This value, although a little high because of the high value from 2 to 8 May, can be regarded as realistic.

It should be pointed out that a rigorous statistical analysis of the data obtained from sediment traps is hampered considerably by the low number of samples secured by these instruments. Our multisample traps as shown here, permit a much improved temporal resolution of sedimentation processes. Soutar et al. (1977) argue the case for observations obtained from sediment traps compared to discrete water-column measurements. They state: "An alternative to increasing the number of measurements to gain sufficient data is to enlarge the scale of each measurement, making each observation representative of a relatively large area and significant period of time." The material collected by traps is equivalent to information integrated over time and, to a certain extent if hydrographical data are available, also over space. However, the reproducibility of individual values is still a matter of conjecture. As our data reflect distinct consistent trends and do not appear haphazard, we feel an interpretation of these results to be justified. In this connection, a discussion of the sampling efficiency of traps is a prerequisite to understanding such results.

\section{Sampling Efficiency of the Sediment Traps}

The particulate matter collected by a sediment trap is frequently regarded as qualitatively and quantitatively representative of the net vertical flux of particles actually sinking through the water adjacent to the trap (= actual sedimentation rate). However, results gained from experimental work show that in the presence of horizontal water movement, the quantity of particles deposited into a sediment trap is dependent on a variety of factors pertaining to shape and environment of the trap (Bröcke1, 1975; Gardner, 1977; Staresinic et al. 1977). 
Gardner (1977) has shown that most particles eventually settling into a sediment trap do not "fall" through the opening but, because of their low sinking rate compared to horizontal current speeds characteristic for marine environments, enter the trap in the process of water exchange with the outside. His results indicate that the amount collected by any sediment trap will depend on the interrelationship between (1) the rate of water exchange between the trap and its environment, and (2) the quantity and sinking rates of the particles comprising the seston load in the water entering the trap. It is best to discuss the causes and effects of these two factors individually, as they are independent of each other.

Rate of Water Exchange between Trap and Environment

The rate of water exchange between the trap and its surroundings is in turn dependent on: (a) the opening $\left(\mathrm{cm}^{2}\right)$ to volume ratio $\left(\mathrm{cm}^{3}\right)$ of the trap; (b) the immediate physical environment (current speeds, density stratification and turbulence spectrum) around the traps, these being partly the result of hydrodynamical characteristics of the traps.

(a) Gardner (1977) found that results obtained from open funnels are always underestimates of actual sedimentation. This is probably because exchange rates and, therefore, turbulence levels, are higher in such vessels than in bottles. our traps - covered funnels with an opening to rim-diameter ratio of $1: 2$ and $a$ surface of opening $\left(\mathrm{cm}^{2}\right)$ to volume $\left(\mathrm{cm}^{3}\right)$ ratio of 1:4 - cannot be compared with open funnels. Gardner (1977) states that "containers with body diameters greater than mouth openings overtrap sediment by a factor which depends on the mouth to body ratio, the concentration of particulate matter and the geometry of the trap." This again is due to lower turbulence levels in such traps. The opening to volume ratio (Gardner's mouth to body ratio) of our traps is equivalent to a cylinder with a height to width ratio of $4: 1$, which is considerably less than that of the containers (generally bottleshaped) tested by Gardner and observed to overtrap sediment. We therefore feel that our traps cannot be regarded per se as having either underestimated or exaggerated actual sedimentation rates, as they do not fall into either of the categories tested by Gardner.

(b) Our data demonstrate that identical traps collected as much as 2 to 3 times more material with increasing depth in the same water column. This phenomenon has also been observed elsewhere (Parsons et al., 1977), and resuspension of sediment has been regarded as an important reason for anomalous collection of material by traps in the same water column. As shown above, resuspended sediment could not have been of importance in the present study.

Lateral transport of allochthonous phytoplankton in deeper layers that bypassed upper traps but reached the lower ones can also be ruled out, particularly in the case of "Moritz" 65, which was situated in the stagnating water below the pycnocline. Therefore, the phytoplankton and its breakdown products collected in the lower traps must have reached these traps by sinking out of the euphotic zone and through the pycnocline, presumably past the upper traps without settling into them. This would indicate underestimation of the actual sedimentation rate by the upper traps, or an overestimation by the lower ones. Removal of accumulated sediment from the traps by resuspension due to rapid currents as described by Bröckel (1975) can definitely be ruled out as well, since the traps were designed specifically to counteract this effect, even at current speeds above $40 \mathrm{~cm} \mathrm{sec}^{-1}$.

It is possible that greater average current speeds around the upper traps compared to the lower ones increased the rate of water exchange between the traps and their surroundings which, in this case, diminished sedimentation into these traps. However, as hydrographical features of the water surrounding the traps sometimes changed drastically during the 6-day collection period, it is difficult to ascertain the direct influence of individual hydrographical events on sedimentation rates as determined by the traps. From the one case where an unusual hydrographical event coincided with such a period ("Moritz" 65, 2 to 8 May), a direct effect of environment on sedimentation rates is indicated.

In spite of the uncertainty involved in comparing hydrographical and sedimentation rate data, it is clear that differences in current speeds alone will not suffice to explain the distinct temporal sequences in the quality and quantity of material characteristic of all traps at both "Max" and "Moritz". Temporal fluctuations in the vertical flux of particles from the euphotic zone must be regarded as the decisive factor.

Quantity and Sinking Rates of Particles Settling-Out of Euphotic Zone

Here again 2 major components can be singled out: (a) the amount of particu- 
late material produced in the euphotic zone minus loss due to respiration in the water column; (b) composition and sinking rates of particles in the environment of the different sediment traps.

(a) Sedimentation rates of phytoplankton derived from anchor station data were several times those measured by the traps at "Moritz" during corresponding periods. This discrepancy, and the fact that biomass production recorded during the 10-day period was much more than sufficient to account for the material collected in the traps over the entire period, leads us to suspect underestimation of actual sedimentation rates by our traps. Further, the zooplankton biomass compared to that of phytoplankton was low. The resultant low grazing pressure was also demonstrated by the paucity of faecal pellets in the sedimented material.

(b) The greater amount collected by lower traps was in contrast to the vertical distribution of particulate matter in the water column. Further, chlorophyll and PPC values decreased much more sharply with depth than the POC values, and it therefore seems unlikely that lower traps selectively accumulated more phytoplankton cells and other pigmented particles from the environment than the upper traps.

Variability in sinking rate of particles with depth is a likely explanation to account for the greater amounts collected by lower traps. Sinking rates of phytoplankton cells are a function of their physiological state and are known to vary by a factor of at least 4 (Smayda, 1970, 1974; Titman and Kilham, 1976). Growing cells have lowest, and cells suffering severe nutrient depletion have the highest sinking rates. The growth pattern of the spring bloom in the Bornholm Basin was interrupted intermittently by bad weather, and cannot be regarded as exponential. This was demonstrated from anchor station data both by nutrient uptake and primary production rates. During such a bloom, nutrient resources of individual cells can be expected to differ considerably within the population, with a certain percentage of cells having higher sinking rates compared to the remainder. Thus, certain portions of the population will be sinking out at maximum sinking rates through the water column followed by other portions at lower sinking rates. Once the latter sink below the euphotic zone, prolonged light deprival, particularly if nutrients have also been depleted in lower layers (as was the case in the present study), will eventually lead to a dete- rioration of their viability and presumably an acceleration of their sinking rates.

One can presume that as the average sinking rate of particles in the intermediate layer was low, they were not collected by the traps suspended here. Cells passing through the halocline had accelerated their downward descent and, after overcoming the initial density barrier, settled through the saline layer fairly rapidly. The lower traps were able to collect this material more effectively because of increased sinking rates. Similarly, phytodetritus formed in the course of sedimentation would result in particles with differing sinking rates. Frustules, chloroplasts and other compact particles will have higher sinking rates than diffuse bits of cytoplasm. The former particles would reach lower traps more rapidly, and this would account for the lower carbon percentage of $D W$ and the lower POC:chl. a equiv. ratios of lower traps.

\section{Discussion}

We postulate that the discrepancy in the quality and quantity of the material collected by traps suspended above one another is due to the combined effects of decreasing current speed and thus turbulent motion, concomitant with increasing sinking rates of phytoplankton and pigmented phytodetrital particles with depth. The implication is that the sampling efficiency of a sediment trap depends on its depth in the water column. Estimating the magnitude of the vertical flux of particles from sediment trap samples therefore becomes a difficult task. In spite of this uncertainty, one can nevertheless draw several conclusions from the results presented here.

Phytoplankton cells, even of such small species as skeletonema costatum, can sink out of the water column to depths below $65 \mathrm{~m}$ within a few days. Neither the weak thermocline nor the strong halocline posed a barrier to the sedimentation of euphotic zone material.

The growth and deterioration phases of the spring bloom, with higher sedimentation rates present in the latter phase, were reflected in the consistent sequence in quality and quantity of material collected by the traps at "Max". It appears that sedimentation of the spring bloom lasted about 3 weeks, with a progressive decline in the quality of organic matter reaching the sea-bed.

"Moritz" was situated in a hydrographically distinct area and, because of the circulation patterns in the Bornholm Sea, 
was not exposed to sudden advection of water from distant areas. The difference in sedimentation pattern between "Max" and "Moritz" was therefore most probably due to a time-lag of 2 to 3 weeks in the development of the bloom at the two stations. Surprisingly, thermocline formation appeared to have no direct influence on either growth or sedimentation of the spring bloom. Perhaps the coastal and therefore sheltered location of "Max" compared to "Moritz" was responsible for the discrepancy.

The similar sequence of material collected by traps in the same water column is indicative of rapid vertical transfer of material, as otherwise a time-lag in the contents of upper and lower traps would have been evident. The different current speeds at different depths as well as the generally reverse direction of currents in upper and lower layers would serve to confuse the picture. Skeletonema costatum cells would require about 4 days to sink from the level of "Max" 32 to "Max" 60 at the maximum recorded sinking rate for this species of $8 \mathrm{~m}$ day-1 (Smayda and Boleyn, 1966). Smayda (1970) suggests that, under certain circumstances, much higher sinking rates are possible. The occurrence of such accelerated sinking rates in nature are also indicated by our data.

The sinking pattern of phytoplankton blooms as surmised from the differences in material collected in upper and lower traps could account for the vertical distribution of phytoplankton as observed at the anchor station. We suggest that the residence time of cells in deeper layers being shorter, their concentration at a given time would be lower than that in upper layers characterized by higher particle concentrations and lower sinking rates. This would hold true even if vertical flux at different depths were the same. Differential sedimentation of phytoplankton could also be a factor influencing horizontal inhomogeneity in biomass during bloom conditions. The result would be "short-term patchiness" lasting days or weeks.

It seems that seciment traps in general are unsuited for determining sedimentation of zooplankton corpses. However, traps located in hostile environments, such as "Moritz" 65, can be expected to give reasonable results. The amount collected by this trap in 5 weeks was equivalent to the standing stock at the anchor station $\left(0.4 \mathrm{~g} \mathrm{Cm}^{-2}\right)$. Natural mortality might appear high, but this was probably because very few planktonic carnivores were present at the time (Boysen, personal communication).
The present investigation was restricted to the spring bloom, when the sedimentation rate of phytoplankton is probably the highest of the year, particularly if large stocks of overwintering zooplankton are lacking. Evidence has been gathered from the sediment record that the sinking of the diatom bloom is a regular annual feature of many localities (Smayda, 1970). This has been observed regularly in Kiel Bight as well (Smetacek, 1975). In the Bornholm Basin and in similar deep basins of the Baltic sea, any input of organic matter to the sediments promotes anoxia and is therefore detrimental to the zoobenthos. In other regions where benthic biomass is more likely to be food-limited, one might expect a direct dependence of the benthic annual cycle on that of sedimentation. The initial supply of fresh organic substances regularly in the spring of each year is bound to have a stimulatory effect on growth and reproduction of benthic animals and might even act as a triggering mechanism for their life cycle.

In general, more information on the annual cycle of sedimentation and its relation to pelagic primary production is required, and sediment traps, in spite of the uncertainties involved, will continue to be a major tool in gathering such information. These results will have to be regarded critically in the future also, but as soutar et al. (1977) have pointed out, standardisation and calibration of traps will considerably improve the quality of information derived from them.

Acknowledgements. This study was supported by the Deutsche Forschungsgemeinschaft. We are indebted to Professor K. Grasshoff, chief scientist on "Meteor Cruise BALTIC 75". We should like to thank the other members of the Plankton Group, Tannenberg: B. von Bodungen, B. Knoppers, M. Kaxl, F. Pollehne and I. Uhlmann for their help; also A. Schurbohm and H. Crnjar.

\section{Literature Cited}

Bröckel, K. Von: Der Energiefluß im pelagischen Ökosystem vor Boknis Eck (Westliche Ostsee), 96 pp. Dissertation, Universität Kiel 1975

Derenbach, J.: Zur Homogenisation des Phytoplanktons für die Chlorophyllbestimmung. Kieler Meeresforsch. 25, 166-171 (1969)

Dietrich, G. und F. Schott: Wasserhaushalt und Strömung. In: Meereskunde der ostsee, pp 3342. Hrsg. von L. Magaard und G. Rheinheimer. Berlin, Heidelberg, New York: Springer-Verlag 1974 
Gardner, W.D.: Fluxes, dynamics, and chemistry of particulates in the ocean, $402 \mathrm{pp}$. Ph.D. Thesis, M.I,T./Woods Hole Oceanographic Institution Joint Program in Oceanography 1977. (Copies available from: W.D. Gardner, LamontDoherty Geological observatory of Columbia University, Palisades, New York 10964, USA)

Hendrikson, P.: Auf- und Abbauprozesse partikulärer organischer Substanz anhand von sestonund Sinkstoffanalysen, $160 \mathrm{pp}$. Dissertation, Universität Kiel 1975

Keunecke, K.H., H. Kohn, W. Krauß, G. Miosga, F. Schott, P. Speth, J. Willebrand und W. Zenk: BALTIC'75 - physikalischer Teil -, Messungen des IfM, der FWG und der DFVLR. Ber. Inst. Meereskde Kiel 11, 1-100 (1975)

Kielmann, J., J. Holtorf and U. Reimer: Data Report BALTIC '75. Ber. Inst. Meereskde Kiel $26,1-155$ (1976)

Kögler, F.C. and B. Larsen: The West Bornholm basin in the Baltic Sea. Geological structure and quaternary sediments. Boreal (In press)

Krause, G.: Ein Beitrag zum Problem der Erneuerung des Tiefenwassers im Arkona Becken. Kielex Meeresforsch. 25, 268-271 (1969)

Lenz, J.: Zur Methode der Sestonbestimmung. Kieler Meeresforsch. 27, 180-193 (1971)

Lorenzen, C.J.: Determination of chlorophyll and pheopigments: spectrophotometric equations. Limnol. Oceanogr. 12, 343-346 (1967)

Matthäus, W., M. Sturm und E. Franke: Einige Aspekte des thermischen Regimes der Ostsee im Sommer 1975 am Beispiel der Bornholmsee. $Z$. Met. 26, 360-372 (1976)

Parsons, T.R., M. Takahashi and B. Hargrave: Biological oceanographic processes, 2nd ed. 332 pp. Oxford: Pergamon Press 1977

Peters, H.: GATE, CTD data measured on the F.R.G. ships, shipboard operation-calibrationediting. Ber. Inst. Meereskde Kiel 22, 1-16 (1976)

Siedler, G. und G. Hatje: Temperatur, Salzgehalt und Dichte. In: Meereskunde der Ostsee, pp 43-60. Hrsg. von I. Magaard und G. Rheinheimer. Berlin, Heidelberg, New York: Springer-Verlag 1974
Simons, T.J.: Topographic and baroclinic circulations in the Southwest Baltic. Ber. Inst. Meereskde Kiel 25, 1-61 (1976)

Smayda, T.J.: The suspension and sinking of phytoplankton in the sea. Oceanogr. mar. biol. A. Rev. 8, 353-414 (1970)

- Some experiments on the sinking characteristics of two freshwater diatoms. Limnol. Oceanogr. 19, 628-635 (1974)

- and B.J. Boleyn: Experimental observations on the flotation of marine diatoms. II. Skeletonema costatum and Rhizosolenia setigera. Limnol. oceanogr. 11, 18-34 (1966)

Smetacek, V.: Die Sukzession des Phytoplanktons in der Westlichen Kieler Bucht. 151 pp. Dissertation, Universität Kiel 1975

Soutar, A., S.A. Kling, P.A. Crill, E. Duffrin and K.W. Bruland: Monitoring the marine environment through sedimentation. Nature, Lond. $266,136-139$ (1977)

Staresinic, N., G.T. Rowe, A.J. Williams III and $D$. Shaughnessey: Measurement of the vertical flux of particulate organic matter with a free-drifting sediment trap. Contr. Woods Hole oceanogr. Instn 3835, 1-7 (1977)

Titman, D. and P. Kilham: Sinking in freshwater phytoplankton: some ecological implications of cell nutrient status and physical mixing processes. Limnol. Oceanogr. 21, 409-417 (1976)

UNESCO: Determination of Photosynthetic pigments in sea water. Monogr. oceanogr. Methodol. (UNESCO) 1, 1-66 (1966)

Zeitzschel, B., P. Diekmann and L. Uhlmann: A new multisample sediment trap. Mar. Biol. 45, 285-288 (1978)

Dr. Victor Smetacek Institut für Meereskunde Düsternbrooker Weg 20 D-2300 Kiel Germany (FRG)

Date of final manuscript acceptance: March 17, 1978. Communicated by O. Kinne, Hamburg 